University of Nebraska - Lincoln

DigitalCommons@University of Nebraska - Lincoln

1988

\title{
Gonotrophic Development in Hypoderma lineatum and $H$. bovis (Diptera: Oestridae), with Notes on Reproductive Capacity
}

\author{
P. J. Scholl \\ 232, Kerrville, TX 78029-0232 \\ J. Weintraub \\ Agriculture Canada Research Station, Lethbridge, Alberta TIJ 4BI Canada
}

U.S. Livestock Insects Laboratory, Agricultural Research Service, U.S. Department of Agriculture, P.O. Box

Follow this and additional works at: https://digitalcommons.unl.edu/entomologyother

Part of the Entomology Commons

Scholl, P. J. and Weintraub, J., "Gonotrophic Development in Hypoderma lineatum and H. bovis (Diptera: Oestridae), with Notes on Reproductive Capacity" (1988). Entomology Papers from Other Sources. 73. https://digitalcommons.unl.edu/entomologyother/73

This Article is brought to you for free and open access by the Entomology Collections, Miscellaneous at DigitalCommons@University of Nebraska - Lincoln. It has been accepted for inclusion in Entomology Papers from Other Sources by an authorized administrator of DigitalCommons@University of Nebraska - Lincoln. 


\title{
Gonotrophic Development in Hypoderma lineatum and $H$. bovis (Diptera: Oestridae), with Notes on Reproductive Capacity
}

\author{
P. J. SCHOLL ${ }^{1}$ AND J. WEINTRAUB ${ }^{2}$
}

\begin{abstract}
Ann. Entomol. Soc. Am. 81(2): 318-324 (1988)
ABSTRACT Gonotrophic development in Hypoderma lineatum (Villers) and Hypoderma bovis (L.) is characterized by initiation and complete growth in larval and pupal stages. Developing oöcytes through six stages to the definitive egg are described. Polytrophic ovarian development is modified; only primary and secondary complements of eggs survive and develop simultaneously. The female emerges from the puparium with its life-long complement of eggs fully developed. Capability to mate and immediately oviposit on host cattle is well suited to the short life span of the nonfeeding fly. Mean reproductive capacity of $H$. lineatum is $516 \pm 54$ (SD) eggs, significantly higher than the $478 \pm 70$ (SD) eggs of $H$. bovis. This system of ovarian development is more efficient than that of other musciform Diptera and contributes to maintenance of cattle grub populations, even when adult fly populations are decimated in areas undergoing organized control.
\end{abstract}

KEY WORDS Insecta, Hypoderma, gonotrophic development, reproduction

CATTLE GRUBS, Hypoderma lineatum (Villers) and Hypoderma bovis (L.), are serious pests of cattle in the Northern Hemisphere. Even under intense control pressure, Hypoderma populations have an unexpected ability to rebound to precontrol levels (Rich 1965, Tarry 1984, Scholl et al. 1986).

After a 7-mo migration within the host, the first instar perforates the skin of the host's back, molts to the second instar and later to the third. Larval development and growth in the "warble" or hypodermal cyst may vary from 3 to $8 \mathrm{wk}$, depending on the time of arrival to the back (Scharff 1950). The mature larva emerges from the host's skin through the breathing hole, drops to the ground, and moves to a sheltered site to form the puparium within which pupal formation and adult development occur.

Nogge (1967) and Boulard (1968) reported that differentiation and early development of female and male gonads of Hypoderma begin in the late second instar. Histological evidence was presented of gonadal elaboration of a mesodermic structure that formed cysts and follicles at the beginning of the third instar.

Adult Hypoderma have no functional mouthparts. Females, whose life span is only 3-5 d, must fly to find a mate and oviposit, using only the energy derived from larval resources accumulated during lengthy development in their bovine hosts. Females emerge with a full complement of eggs and must wait only $1 \mathrm{~h}$ until they have hardened to flight capability before they are able to mate

${ }^{1}$ U.S. Livestock Insects Laboratory, Agricultural Research Service, U.S. Department of Agriculture, P.O. Box 232, Kerrville, TX 78029-0232.

${ }^{2}$ Agriculture Canada Research Station, Lethbridge, Alberta T1J 4B1 Canada. and oviposit (Bishopp et al. 1926, Mote 1928). The two sexes meet at specific aggregation sites (Gansser 1956, Catts et al. 1965).

Descriptions of the reproductive organs (Carpenter \& Hewitt 1914, Mote 1929, Gooding \& Weintraub 1960), mating and oviposition (Weintraub 1961), and hybridization experiments between the two species (Weintraub et al. 1968) have been reported but do not describe gonotrophic development.

The number of eggs per Hypoderma female has been estimated to be 400 (Gibson \& Twinn 1936), 500 (Bishopp et al. 1929), and 500-800 (Scharff 1950). Many of these estimates were based on few specimens, and some (for example, 800 eggs) may have been repetitions of earlier general estimates in the literature. Evstaf'ev (1982) estimated reproductive capacities in the U.S.S.R. to be 383 and 426 eggs per female of $H$. lineatum and $H$. bovis, respectively.

Increased use of modeling of insect populations, including Hypoderma, has created a need for more accurate measurements of reproductive capacity and a description of the gonotrophic cycle leading to oviposition for these two species (Weintraub 1978). Here we address this need, using a technique described for gonotrophic development in other Diptera (Vogt et al. 1974, Scholl 1980).

\section{Materials and Methods}

Third instars, age unknown, of both species were manually removed from their warbles, dissected, and assigned to approximate age based on size and development of pigmentation. Larvae of $\mathrm{H}$. lineatum that emerged from the backs of cattle were collected and held in an incubator in 50-60\% $\mathrm{RH}$ 
at 15:9 (L:D) photoperiod and 27 and $15^{\circ} \mathrm{C}$, respectively, for pupation and development to adult emergence. At least three specimens were frozen each day at $-40^{\circ} \mathrm{C}$ for later dissection. Because of a shortage of available $H$. bovis puparia, only three female pupae of known developmental age were dissected for comparison with the developmental sequence for $\boldsymbol{H}$. lineatum. Ovaries were removed from about $150 \mathrm{H}$. lineatum and $75 \mathrm{H}$. bovis larvae and stained with neutral red dye to enhance photography as described by Vogt et al. (1974) for Phaenicia (=Lucilia) cuprina (Wiedemann). Representative samples of ovaries were photographed and assigned to age classes by the method described by Scholl (1980) for the stable fly, Stomoxys calcitrans (L.). We use the terminology of the descriptions by Fraenkel \& Bhaskaran (1973) and Thomas (1985) for pupal descriptions and developmental sequences.

Pupal duration was expressed as a percentage of development rather than number of hours or days, to accommodate a larger variety of rearing conditions. Data from reared puparia showed that the time span from larval exit from the host until adult emergence could range from 13 to more than 72 $\mathrm{d}$, or daily rates of 7.69 and $1.39 \%$, respectively, for the extremes of environmental conditions. The comparison of pupal characteristics and gonotrophic development was made in the context of percentage of development that had elapsed.

Reproductive capacity of each species was determined by dissection of $105 \mathrm{H}$. lineatum and 122 $H$. bovis females that had been reared and had oviposited in the laboratory (Weintraub 1961). After maximal oviposition in the laboratory, the flies were dissected, and counts were made of eggs remaining in the genital tract. This number was added to the total number of eggs laid to determine reproductive capacity. A Student's $t$ test was performed to test differences in egg production between the two species.

Voucher specimens have been sent to the Department of Entomology, University of Guelph, Guelph, Ontario, Canada.

\section{Results}

Gonotrophic Development. Late third instars almost fully grown but still without pigmentation (Fig. 1) had ovarioles filled with granules of no obvious structure or organization (Fig. 2). When the larval cuticle began to change from whiteyellow to tan-gray, two Stage 0 follicles formed in each ovariole (Fig. 3). The more proximal of the two was at first slightly larger and more differentiated, but by the time the larval cuticle began to melanize (Fig. 4), both follicles in Stage 1 were entirely enclosed, with a cell wall and nurse cells visible (Fig. 5).

When the fully melanized larva (Fig. 6) emerged from the host's back for pupariation, both follicles in each ovariole in early Stage 2 were equal in size and stage of development (Fig. 7). Yolk deposition, which became visible at this point, was restricted to the distal $10 \%$ of each follicle.

It is very difficult to age Hypoderma larvae accurately; however, emergence from the host is a distinct developmental landmark, consistent for both species, with which assignment to a particular age can be based (Table 1). Shortly after pupariation, the oöcytes began to enlarge and a greater proportion (20-35\%) of each follicle was occupied by yolk (Fig. 8) for the remainder of Stage 2. At this stage the nurse cell chamber still was the dominant feature of the egg. The shape of the egg changed from nearly round at the beginning of Stage 2 to ovoid.

Stage 3 represented the period of greatest growth in size of the egg. By the end of this stage the expanding yolk and oöcyte had reduced the nurse cell chamber to $<25 \%$ of the total length of the egg (Fig. 9). During Stage 3, the nucleus of the Hypoderma egg moved to the middle of the follicle as the disintegrating nurse cells were pushed to the distal end. The ovoid follicle found at the beginning of this stage became distinctly elongated. At the end of Stage 3,>50\% of pupal development had occurred (Table 1).

At the time the pupa entered the red-eyed pharate adult stage (Fig. 10), the oöcyte entered Stage 4 and the disintegrating nurse cells still occupied $<25 \%$ of the total egg length (Fig. 11). As the pupa approached $60 \%$ of its development, a feature characteristic of the Hypoderma egg began to form. With most of the egg volume occupied by yolk, and the nucleus often found at the margin of the follicle (Fig. 12), the proximal end of the developing chorion began to "bud" within each follicle and the attachment organ (Cogley et al. 1981) took shape (Fig. 13 and 14). This organ and the egg proper continued development through the rest of Stage 4 to the 80 th percentile of pupal development.

The final $20 \%$ of pupal development was concurrent with Stage 5 egg development; here the chorion hardened, the disintegrated nurse cells were reduced to a small cluster of cellular debris, and the fully developed attachment organ reached its definitive form (Fig. 15). Even at this stage of development, eggs were still paired within each ovariole, and dissections normally revealed two ova enclosed within a thin, common follicular membrane (Fig. 16).

When the female fly emerged, the eggs began to fill the lateral oviducts and common oviduct; the attachment organ preceded the egg proper (Fig. 17). When the flies hardened to flight condition, females of both species were capable of mating and ovipositing (Fig. 18). During oviposition, the attachment organ grasped each hair, much as a sausage is placed inside a bun. $H$. lineatum normally attaches its eggs in long strings (Fig. 19), the attachment organs touching each other (Fig. 20), 

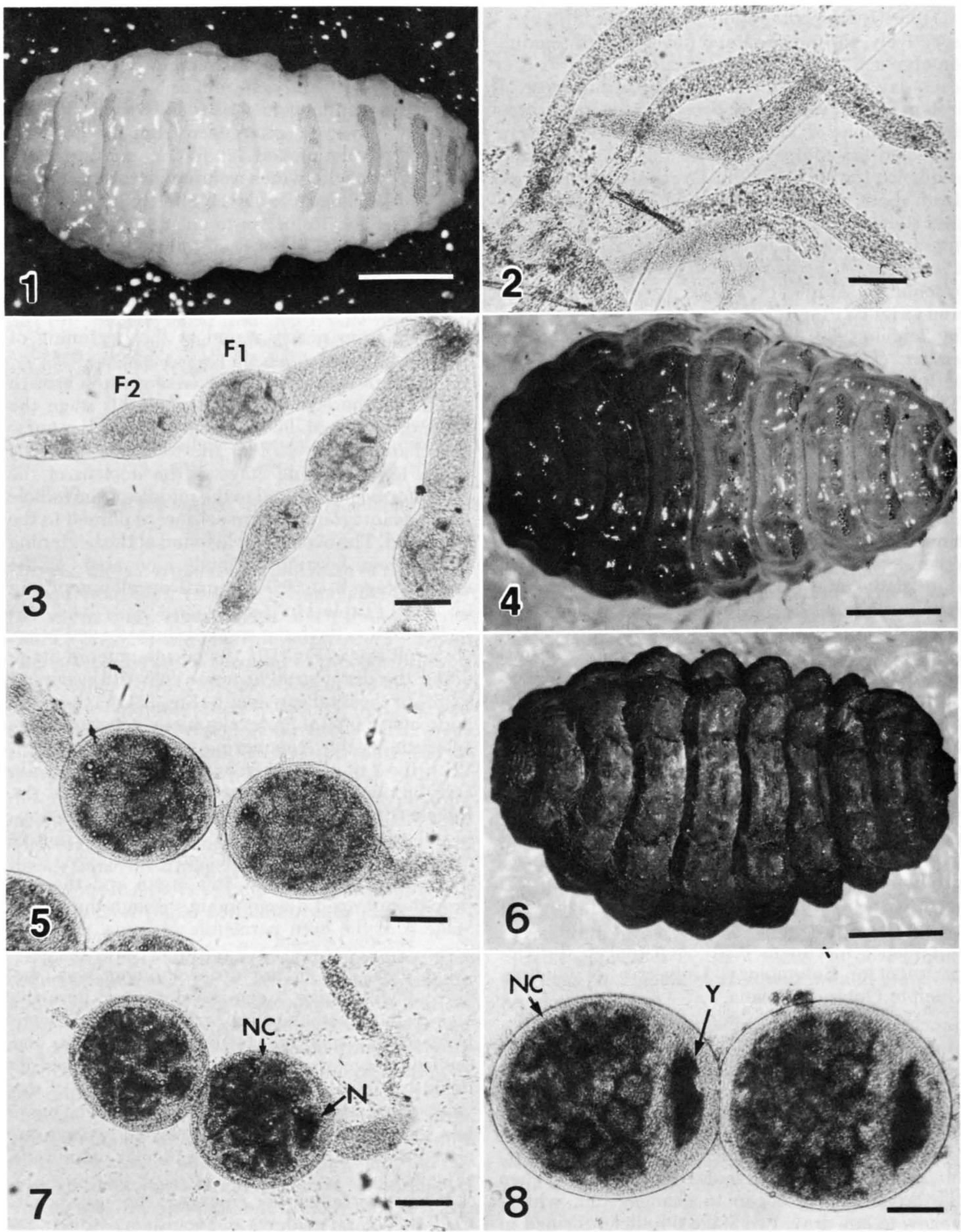

Fig. 1-8. F1, follicle 1; F2, follicle 2; N, nucleus; NC, nurse cells; $\mathrm{Y}$, yolk. Bar lines in Fig. 1, 4, and 6, $5 \mathrm{~mm}$; all others $100 \mu \mathrm{m}$. (1) Middle to late Hypoderma lineatum third instar, dorsal view. (2) Ovarioles from middle to late third-instar $H$. lineatum. (3) Ovarioles from late third-instar $H$. lineatum with two distinct follicles forming within each ovariole; F1 formed slightly ahead of F2; both in Stage 0. (4) Late third-instar H. lineatum with cuticle partly melanized. (5) Stage 1 follicles from late third-instar H. lineatum; both follicles of equal size and development. (6) Fully melanized $H$. bovis larva which had emerged from animal. (7) Stage 2 follicles from emergent $H$. lineatum; nurse cells and nucleus readily discernible. (8) Late Stage 2 follicles from $H$. lineatum pupa; nurse cells still evident; yolk deposition in progress. 
Table 1. Development, larval and pupal deseriptions, and gonotrophic development of Hypoderma

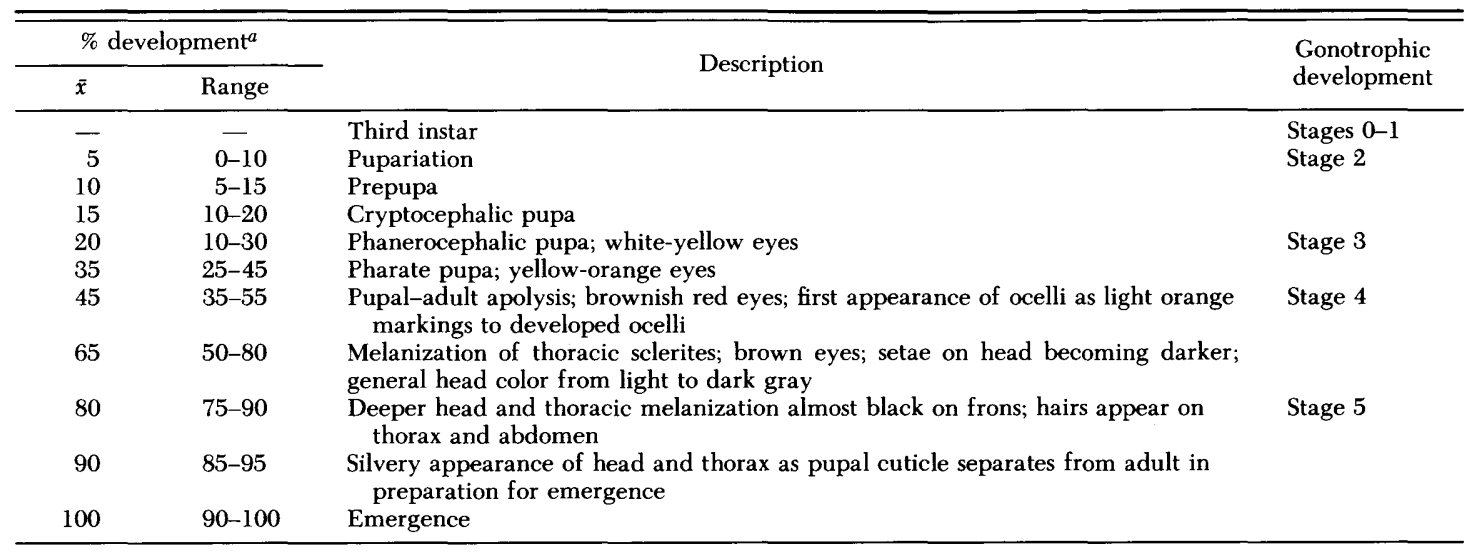

a Percent development was measured from the time that grubs were collected daily in catching devices on host cattle. Variable development was observed, ranging from dark tan grubs (which do not pupariate or develop further), through completely melanized mature larvae, to formed puparia. As a result, we have accommodated ranges of development around an estimated mean.

while $H$. bovis attaches its eggs in the same manner, but singly on each hair.

Puparia, whose opercula can be easily removed, can be aged to a relatively accurate percentile of physiological development by comparison with information in Table 1. Removal of the operculum also exposes the head for ready determination of sex. Generally, a space $>2 \mathrm{~mm}$ between the compound eyes indicates a female pupa. Puparia handled in this manner can be returned to an incubator for further maturation with no additional mortality for the remainder of their development to emergence (Weintraub, unpublished).

Reproductive Capacity. Adult female $H$. lineatum and $H$. bovis from the Montana-Alberta area had an average reproductive capacity of 515.9 and 478.2 eggs per female (SD $=53.5$ and 70.4 ; range 377-665 and 243-634), respectively, the reverse of relative reproductive capacities of the two species given by Evstaf'ev (1982). Reproductive capacities in the two species were statistically different $(t=$ 4.48; $\mathrm{df}=225$ ) at the $P<0.001$ level. This was consistently true, although $H$. bovis females are larger and stouter than $H$. lineatum females. The increased bulk seems to be mainly the flight muscles required for $H$. bovis's very active oviposition attack.

\section{Discussion}

Nogge (1967) and Boulard (1968) described the development of Hypoderma spp. gonads from sexually undifferentiated tissue in first instars through early ovarial differentiation in the second instar, to the appearance of gonocytes with precursors of follicular cells in a germarium in the early third instar. In the late third instar, with both its follicles formed, we could not discern a functioning germarium of the type normally associated with dipteran ovarian development. The sequence suggests that the germarium formed early and was absorbed as the paired follicles developed. This unusual pattern for Diptera may have evolved with the short life span of the adult Hypoderma female. The developmental pattern and the absence of a germarium do not permit Hypoderma to form subsequent batches of eggs, as do other Diptera. Hypoderma also differ from other dipterans in the simultaneous development of the two follicles within each ovariole during all five stages of egg development.

The growth of eggs in the ovary, which represents mostly the accumulation of yolk, involves the utilization of much nutrient material. This material is obtained either from the daily food of the insect or from food reserves stored in the body, principally in the fat tissue. Insects that do not feed in the imaginal stage (such as Hypoderma) draw all of the egg material from the latter source (Snodgrass 1935).

Hypoderma, and possibly related Oestridae that do not feed as adults, can accumulate nutrients only during the feeding larval stage. Diptera that feed regularly as longer-lived females can produce a series of egg batches over time, whether autogenously or not; the later eggs are developed in the adult. These flies normally oviposit fewer primary eggs than Hypoderma but oviposit variable numbers of eggs in subsequently developed batches. However, vulnerable to mortality and physiological constraints, they may die before their full ovipositional potential is realized.

In contrast, the gonotrophic development of $\mathrm{Hy}$ poderma is initiated in the nutrient-rich environment of the larva and completed by the relatively protected pupa, leaving the adults free to begin quickly the oviposition sequence. Furthermore, an increased number of available eggs is made possible by the simultaneous development of two batches of eggs, even though subsequent batches are forfeited. Hypoderma has adapted to a brief adult life span, with active pursuit of an oviposition site on cattle hairs, an apparatus for fastening the eggs 

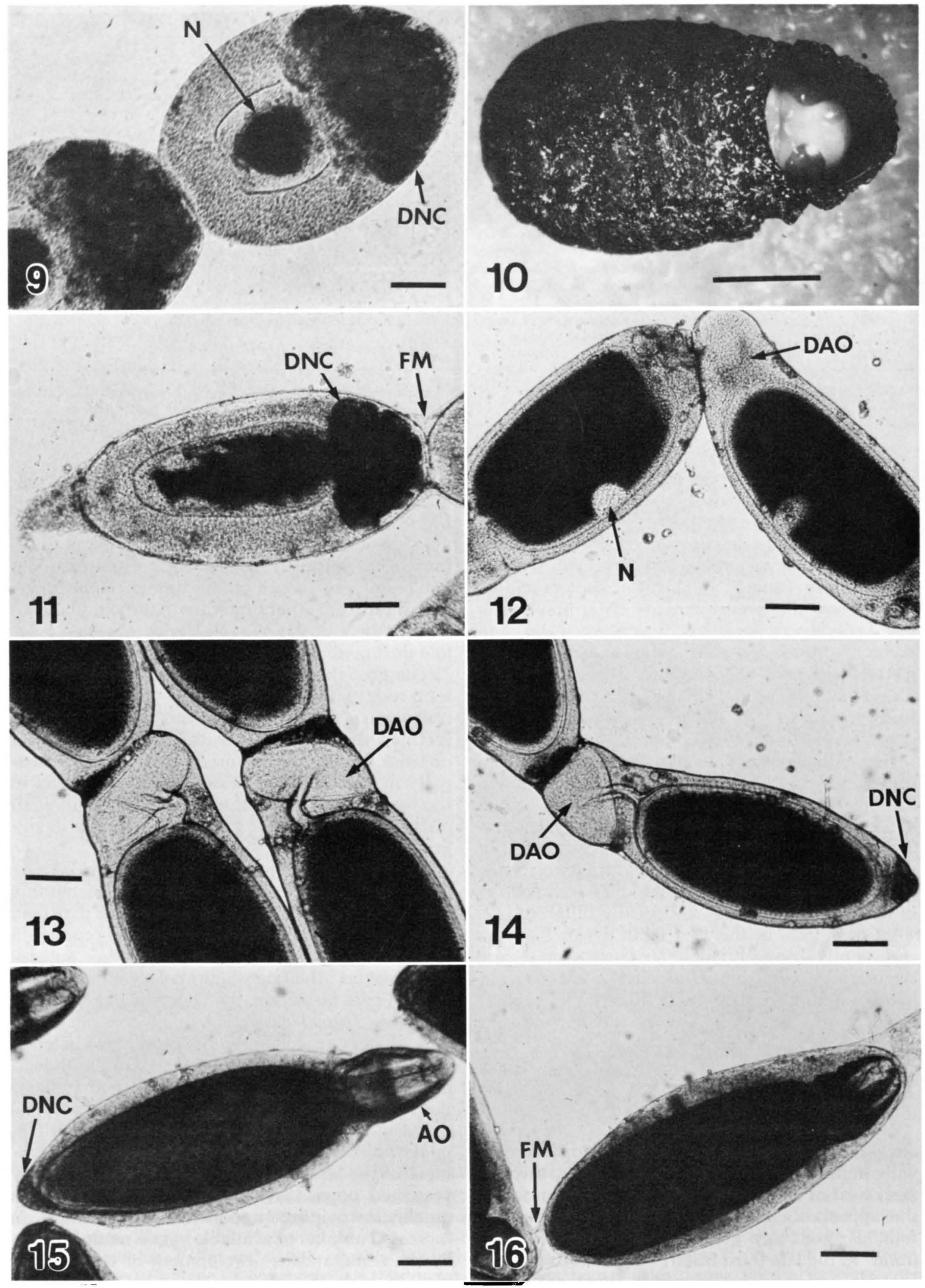

Fig. 9-16. AO, attachment organ; DAO, developing attachment organ; DNC, disintegrating nurse cells; FM, follicular membrane; N, nucleus. Bar line in Fig. 10, $5 \mathrm{~mm}$; all others $100 \mu \mathrm{m}$. (9) Stage 3 follicles from H. lineatum with nucleus in center of egg displacing disintegrating nurse cells. (10) Red-eyed pharate adult stage of $H$. lineatum. 


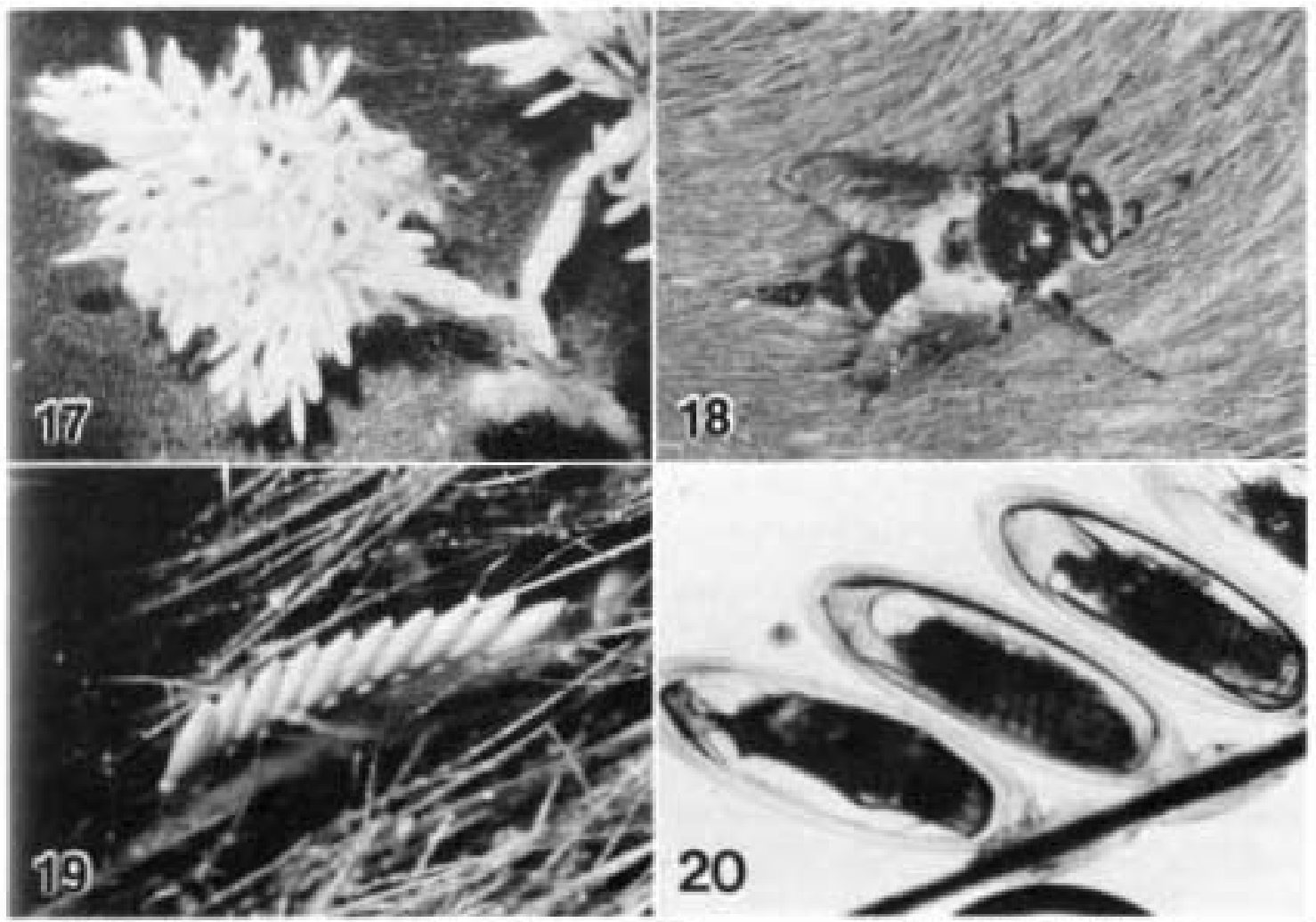

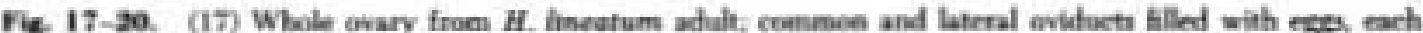

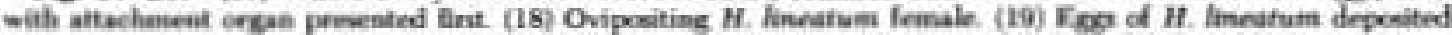

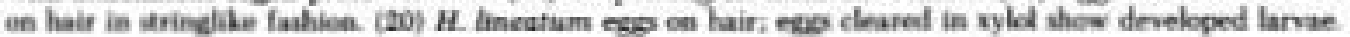

ancurely (Cogley et al. 1981), and situated for direct invasioe of the host by the hatching larvae (Nebon a Weintraub 1972 ), Gonotrophic activities that normally become a drain on adult bodily resources coincide with larval access to nutrients, the residues of which are carried forward to fuel the activities of the nonfeeding adult. Female Hypoderma imasoes emerse ready for immediate fertilization and oviposition and ure able to infest hosts with a large number of eggs in u short time (Weintraub 1961)

All adults of Gasterophilidae and Oestridae have reduoed mouthparts and cannot feed (Zumpt 1965). like the two species investigated here. Adult $\mathrm{Cu}$ terebridae have similar ecological behavior and hou-parasitic life cycles with more developed but nonfeeding mouthrarts (Catts 1982), and may provide an intermediate stage relating back to muscoid and calliphoroid roots of this specialized mylasis group (Zumpt 1965). Further study of these forms has been initiated for possible evolutionary relationaips or for determining the ecological role of oogenesis in maintenance and regulation of their popalations. It would be internting to determine if other members of these families follow similar patterns of ovarial development that featured completion within the immature inseet stages and stmultaneous maturation of more than a primary follicle within cach ovariole.

\section{Ackeowledyment}

The authon expres their appreciation to $\mathrm{C}$ C. Barrett for providine bionogical materials, to $\mathbf{K}$. Roberts and G. Shore fer technioal aisisanee, and to E. Cushul for photoeraptn (Tie, 15 and 19]. All other photographs were taim by the xeniar anthar, and were copied and procrised fer puthlinatbon by X. C. Sinclair, Photoeraphic Unit, Acriculture Canada Remarrh Station, Lethiridge. Altwerta

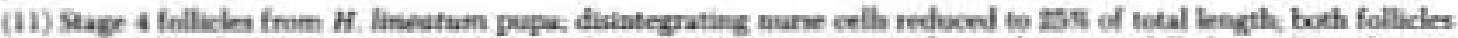

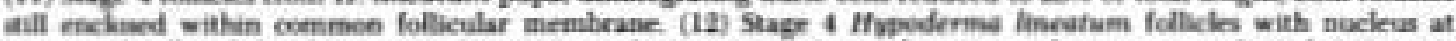
margin of eell and developing attachinent ougan beginning (13) Developins aftachment argans from late Stage 4 H. linestam follicies (14) Stage $4 \mathrm{H}$. tnestum follicle with diaintegruted narse cello reduced to <10\% of egg length at diatal end of each follicle. (15) Late Stage 4 follicle from $\boldsymbol{H}$ bowir with disintoxyated marne cells reduced to small chater of debris and attachment argan mearly developed. (16) Staus 5. Fully developed follicles from emergent female $U$. Limentum ovary both follicles still enclosed within follieular unembrase 


\section{References Cited}

Bishopp, F. C., E. W. Laake, H. M. Brundrett \& R. W. Wells. 1926. The cattle grubs or ox warbles, their biologies and suggestions for control. U.S. Dep. Agric. Bull. 1369. Washington.

Bishopp, F. C., E. W. Laake \& R. W. Wells. 1929. Cattle grubs or heel flies with suggestions for their control. U.S. Dep. Agric. Farmers Bull. 1596. Washington.

Boulard, C. 1968. Differenciation et developpement des gonades males et femelles chez les larves d'Hypoderma bovis et d'Hypoderma lineatum (Dipt., groupe biologique des Oestriformes). Ann. Soc. Entomol. Fr. (NS) 4: 349-364.

Carpenter, G. H. \& T. R. Hewitt. 1914. The reproductive organs and the newly hatched larva of the warble fly (Hypoderma). Sci. Proc. R. Dublin Soc., N.S. 14: 268-289.

Catts, E. P. 1982 . Biology of New World bot flies: Cuterebridae. Annu. Rev. Entomol. 27: 313-338.

Catts, E. P., R. Garcia \& J. H. Poorbaugh. 1965. Aggregation sites of males of the common cattle grub, Hypoderma lineatum (De Villers) (Diptera: Oestridae). J. Med. Entomol. 1: 357-358.

Cogley, T. P., J. R. Anderson \& J. Weintraub. 1981. Ultrastructure and function of the attachment organ of warble fly eggs (Diptera: Oestridae: Hypodermatinae). Int. J. Insect Morphol. Embryol. 10: 7-18.

Evstaf 'ev, M. N. 1982. The effect of acquired immunity on warble flies Hypoderma bovis and $H$. lineatum (Hypodermatidae) in hypodermatosis in cattle. Parazitol. 16: 476-483 (translated from Russian).

Fraenkel, G. \& G. Bhaskaran. 1973. Pupariation and pupation in cyclorrhaphous flies (Diptera): terminology and interpretation. Ann. Entomol. Soc. Am. 66: 418-422.

Gansser, A. 1956. Warble flies and other Oestridae: biology and control. Hides and Allied Trades Improvement Society, Surrey, England.

Gibson, A. \& C. R. Twinn. 1936. Warble fly control in Canada. Sci. Agr. 17: 179-198.

Gooding, R. H. \& J. Weintraub. 1960. The genitalia of Hypoderma bovis (L.) and H. lineatum (De Vill.) (Diptera: Oestridae). Can. J. Zool. 38: 565-574.

Mote, D. C. 1928. The ox warble flies. Ohio Agric. Exp. Stn. Bull. 428.

1929. The reproductive system of the warble fly, $H y$ poderma bovis DeGeer. Ann. Entomol. Soc. Am. 22: $70-80$.

Nelson, W. A. \& J. Weintraub. 1972. Hypoderma lineatum (De Vill.) (Diptera: Oestridae): invasion of the bovine skin by newly-hatched larvae. J. Parasitol. 58: 614-624.

Nogge, G. 1967. Ovarienentwicklung und Oenocyten in der Larve der grossen Dasselfliege: Hypoderma bovis (De Geer) (Diptera, Oestridae). Thesis, University of Bonn.

Rich, G. B. 1965. Systemic treatments for control of cattle grubs Hypoderma spp. in an isolated range herd. Can. J. Anim. Sci. 45: 165-172.

Scharff, K. D. 1950. Cattle grubs-their biologies, their distribution, and experiments in their control. Mont. Agric. Exp. Stn. Bull. 471.

Scholl, P. J. 1980. A technique for physiologically age-grading female stable flies, Stomoxys calcitrans (L.). Univ. Nebr. IANR Res. Bull. 298.

Scholl, P. J., D. D. Colwell, J. Weintraub \& S. E. Kunz. 1986. Area-wide systemic insecticide treatment for control of cattle grubs, Hypoderma spp. (Diptera: Oestridae): two approaches. J. Econ. Entomol. 79: 1558-1563.

Snodgrass, R. E. 1935. Principles of insect morphology. McGraw-Hill, New York.

Tarry, D. W. 1984. Eradication of warble flies: the problems ahead. State Vet. J. 37: 178-183.

Thomas, D. B. 1985. Phenology of intra-puparial metamorphosis in horn fly and stable fly; a note on the diapause stage of the horn fly. Southwest. Entomol. 10: 139-149.

Vogt, W. G., T. L. Woodburn \& M. Tyndale-Biscoe. 1974. A method of age determination in Lucilia cuprina (Wied.) (Diptera, Calliphoridae) using cyclic changes in the female reproductive system. Bull. Entomol. Res. 64: 365-370.

Weintraub, J. 1961. Inducing mating and oviposition of the warble flies Hypoderma bovis (L.) and $H$. lineatum (De Vill.) (Diptera: Oestridae) in captivity. Can. Entomol. 93: 149-156.

1978. Pilot test of sterile insect releases for warble fly control, pp. 48-53. In G. C. R. Croome \& D. B. Wilson [eds.], Research highlights-1977. Agric. Can. Res. Station, Lethbridge, Alberta.

Weintraub, J., R. H. Robertson \& R. H. Gooding. 1968. Experiments in hybridizing the warble flies Hypoderma lineatum (De Villers) and H. bovis (Linnaeus) (Diptera: Oestridae). Can. J. Zool. 46: 129-133.

Zumpt, F. 1965. Myiasis in man and animals in the Old World. Butterworths, London.

Received for publication 10 March 1987; accepted 21 September 1987. 